\title{
anemon
}

Muş Alparslan Üniversitesi Sosyal Bilimler Dergisi

Journal of Social Sciences of Muş Alparslan University

Yı//Year: 2016 • Cilt/Volume: 4 • Sayı/Number: 2

ISSN: 2147-7655 • e-ISSN: 2149-4622

ÖZGÜN ARASTTIRMA O ORIGINAL ARTICLE

\section{Bilimsel Araştırma Yöntemleri Dersinin Öğretmen Adaylarının Bilimsel Epistemolojik İnançları ve Bilimsel Araştırmalara Yönelik Tutumları Üzerindeki Etkisi ${ }^{\mathrm{a}}$}

\author{
Nazım ÇOĞALTAY $1, b$ \\ ${ }^{1}$ Yrd. Doç. Dr., Muş Alparslan Üniversitesi, Eğitim Fakültesi, Eğitim Bilimleri Bölümü- Muş/Türkiye \\ Başvuru tarihi: 08 Ağustos 2016 Düzeltme tarihi: 10 Ekim 2016 Kabul tarihi: 18 Ekim 2016
}

Öz

$\mathrm{Bu}$ araştırmada eğitim fakültelerinde okutulan ve zorunlu dersler arasında yer alan "bilimsel araştırma yöntemleri” dersinin öğretmen adaylarının bilimsel epistemolojik inançları ve bilimsel araştırmaya yönelik tutumları üzerindeki etkisi incelenmiştir. Araştırmaya 2015-2016 eğitimöğretim yılının ikinci döneminde Muş Alparslan Üniversitesinin sınıf öğretmenliği ve okul öncesi öğretmenliği anabilim dallarında öğrenim gören 135 öğretmen adayı katılmıştır. Araştırma deneysel desenlerden tek gruplu öntest-sontest modeline göre yapılandırılmıştır. Verilerin analizinde aritmetik ortalama, ilişkili gruplar t testi (paired $t$ test) ve bağımsız gruplar $t$ testi (independent $t$ test) uygulanmıştır. Araştırmada öğretmen adaylarının aldıkları "bilimsel araştırma yöntemleri" dersinin bilimsel epistemolojik inançlarına istatistiksel olarak anlamlı bir etkisinin olmadığı saptanmıştır. Söz konusu dersin öğretmen adaylarının bilimsel araştırmalara yönelik tutumları üzerinde ise olumlu yönde etkisi ortaya çıkmıştır.

\section{Anahtar Kelimeler}

Bilimsel Epistemolojik İnanç, Bilimsel Araştırmaya Yönelik Tutum, Pozitivizm, Post-Pozitivizm

\footnotetext{
a Bu çalışma 12-14 Mayıs 2016 tarihinde Aydın/ Kuşadası'nda düzenlenen 11. Ulusal Eğitim Yönetimi Kongresinde bildiri olarak sunulmuştur.

b Sorumlu Yazar/Correspoding Author: Muş Alparslan Üniversitesi Kampüsü, Eğitim Fakültesi, Diyarbakır Yolu 7. Km, 49250, Muş / Türkiye.

e-posta: n.cogaltay@alparslan.edu.tr 


\section{The Effect of the Methods of Scientific Research Course on Preservice Teachers' Scientific Epistemological Beliefs and Attitudes Towards Scientific Researches}

\section{Abstract}

The purpose of the study is to determine the effect of methods of scientific research course which is taught in faculties of education on preservice teachers' scientific epistemological beliefs and attitudes towards scientific researches. The study was carried out at the Faculty of Education in Mus Alparslan University. Totally 135 teacher candidates constitute the sample of the research. The research design of the study was experimental type that included one group pre-test and posttest model. At the end of this research, it was determined that teacher candidates' level of attitude towards scientific researches changed positively after they took courses. However, it was determined that teacher candidates' scientific epistemological beliefs didn't change after they took courses.

\section{Keywords}

Scientific Epistemological Beliefs, Attitude Towards Scientific Research, Positivism, PostPositivism

\section{GÍRIŞ}

Öğretmenlik mesleğinin bir toplumun sosyal, kültürel ve ekonomik yönlerini doğrudan etkileyen bir uzmanlık alanı olması, öğretmen yetiştirme yeterliliğini bir ülkenin çözmesi gereken öncelikli problemleri arasına yerleştirmiştir. Değişimin ve gelişimin önemli düzeyde ivme kazandığı günümüzde sadece alan bilgisi iyi olan öğretmen anlayışı ihtiyaçlara cevap verememektedir. Etkili öğretmen, yeterli alan bilgisinin yanında, uygun öğretim strateji, yöntem ve tekniklerini öğrencilerin bireysel farklılık ve yeterliliklerine göre belirleyen, ölçmenin doğasını ve sınırlılıklarını bilerek değerlendirmesine olabildiğince objektiflik kazandıran, bilimin doğasına ilişkin farkındalı̆̆ı olan, destekleyici sınıf yönetimi anlayışını merkeze alan ve eğitim sürecinin her aşamasında uygun rehberlik davranışlarını sergileyebilendir (Dillon ve Muguire, 1998; Engin, 2012; Nunan, 2004). Özellikle eğitimin bir bilim olarak ortaya çıkmasıyla birlikte öğretmenlik mesleği daha da önem kazanmaya başlamış ve öğretmenlik mesleğinin yerine getirilebilmesinde adayların özel bilgi ve beceriler ile donatılması gerekliliği ortaya çıkmıştır (Erden, 1998).

Ülkemizde öğretmen yetiştirme sisteminin ilk kurumsal örneği, İstanbul'da 16 Mart 1848 'de "sıbyan mektebleri" ve "rüştiyeler" in öğretmen ihtiyacını karşılamak üzere 
kurulan "Darul Muallimin" dir. Daha sonraları 1868 yılında, sadece ilköğretime öğretmen yetiştirme misyonunu üstlenmiş olan "Darulmuallimin-i İptidaiye (ilk ve ortaokul)" kurulmuş, bu kuruma 1874 yılında "idadi (lise)" bölümü de eklenerek öğretmen ihtiyacı karşılanmaya çalışılmıştır. Cumhuriyet öncesi dönemde söz konusu öğretmen yetiştirmek amaciyla kurulan okullarda okutulan derslerin daha çok alan dersleri ile ağırlıklı olduğu (Türkçe, cebir, tarih, coğrafya vb.), öğretmenlik meslek bilgisi derslerinden sadece usuli tedrisiyeye (öğretim yöntemleri) yer verildiği görülmektedir. Cumhuriyetin ilan edilmesinin ardından öğretmen yetiştirmede değişik tip ve düzeyde öğretim kurumlarının (Ana muallim mektebi, köy öğretmen okulları, köy enstitüleri, gazi eğitim enstitüsü, Yüksek Öğretmen okulu vb.) 1982 yılındaki yasal değişikliğe kadar işe koşulduğunu görmek mümkündür (Akyüz, 2014; Ergün, 1987; Taşdemirci, 2010). 1982 y1lında çıkarılan 2547 sayılı Yükseköğretim Kanunu'nda tüm öğretmen yetiştiren kurumların üniversitelere bağlanmasına karar verilmiştir. Bu tarihten itibaren ilkokul öğretmeni olacak adaylar eğitim yüksek okulları tarafından 2 yıllık bir eğitime tabi tutulmuş, bu süre daha sonra 4 yıla çıkarılmıştır. 1998 yılında eğitim fakülteleri Yüksek Öğretim Kurumu (YÖK) tarafından yeniden yapılandırılmış ve öğretmen adaylarına okutulacak dersler ve içerikleri düzenlenmiştir (YÖK, 1998a; YÖK, 1998b). Son olarak yine YÖK'ün 2006 yılında yaptığı çalışmalar ile eğitim fakülteleri yeniden ele alınmış ve nihai olarak 2007 yılında eğitim fakültelerinde açılacak bölüm ve okutulacak derslere ilişkin düzenlemeye son hali verilmiştir. $\mathrm{Bu}$ son düzenlemede, öğretmen adaylarına verilen alan bilgisi, genel kültür ve öğretmenlik meslek bilgisi derslerinin ağırlıklarında değişikliğe gidilerek genel kültür derslerinin ağırlığının arttırıldığı görülmektedir. Buna ilişkin genel kültür dersleri içerisinde yer alan "bilimsel araştırma yöntemleri" dersinin tüm öğretmenlik bölümlerinde okutulan zorunlu dersler arasına alındığı görülebilmektedir (YÖK, 2007). Bu 2 kredilik teorik ders ile öğretmen adaylarında bilimin temel kavramları (olgu, bilgi, evrensel bilgi vb.), bilimsel araştırmanın yapısı, bilimde kullanılan yöntemler, araştırma modeli, evren, örneklem, veri toplama teknikleri gibi konularda farkındalık yaratmak amaçlanmıştır. Ayrıca öğretmen adaylarının mesleki yaşamlarında bilimsel araştırmalar yaparak ya da yapanlara katkı sunarak bilimsel çalışmalara destek olmaları ve kendi sorunlarını çözerken bilimsel yöntemlerden yararlanabilmelerinin sağlanması da amaçlanmaktadır (Cafoğlu, 1998; Demircioğlu, 2006; Kılıç ve Acat, 2007).

Bilginin kaynağına ilişkin tartışmalar, insanlığın varoluş süreci kadar eskiye dayandırılabilir. Temel problem hangi kaynağın daha doğru bilgi sunduğuna ilişkindir. Bilginin mahiyeti, genel geçer bir önermenin nasıl oluşturulacağı, geçerli bir bilgiye ulaşmada hangi kaynağa başvurulacağı bilgi felsefesinin (epistemoloji) sorunudur. Bilim ve düşünce tarihi boyunca bu sorulara cevap vermeye çalışan iki ana yaklaşım olan pozitivist ve post-pozitivist tartışmalarda da bilginin kaynağına ilişkin anlaşmazlıklar ön plandadır (Pomeroy, 1993). Pozitivizm bir felsefedir ve sadece katı bilimsel yöntem aracılı̆̆ıyla elde edilen bilginin geçerli olduğunu savunur. Bilginin tek kaynağının deney ve gözlem olduğunu savunan empirik bir bakış açısı söz konusudur. Bilimsel bilginin üretiminde araştırmacının öznel bakış açısının dışta tutulduğunu varsayarak tamamen objektif bir sürece vurgu yapar (Cohen \& Manion, 1994; Neuman, 2006). Pozitivizm rasyonalizm ve empirizmin bir sentezi olarak kabul edilebilir. Pozitivizmde açık olarak iddia edilmese de tek bir bilim mantığı vardır. Yapılan her araştırma şayet bu mantık ile uyumlu ise bilim olarak kabul edilir. Bu mantıkta genel anlamda fiziktir. Diğer tüm bilimlerin fizik bilimine indirgeme çabası pozitivizmin özündedir. Pozitivizmin mimarı 
olarak kabul edilen Auguste Comte'nin sosyolojiyi "sosyal fizik" olarak isimlendirmesi pozitivizmin bu indirgemeci anlayışını göstermektedir (Şimşek, 1997). Pozitivizm, toplumsal olguların doğal olgulardan farklı olmadığını dolayısıyla ancak doğa bilimlerinde uygulanan yöntemlerle toplumsal olayların anlaşılabileceğini iddia etmektedir (Greenfield, 1986). Buna karşın post-pozitivist yaklaşım (yorumsamacı paradigma) özellikle sosyal bilimler açısından pozitivizmin ilkelerini ve dayanaklarını sorgular ve eleştirir. Bu yaklaşım pozitivizmin insan davranışlarını yeterli düzeyde açıklayamadığını ve içerdiği araştırma metodolojisine bağlı kalınarak yapılan araştırmaların güvenilir sonuçlar doğurmadığını iddia etmektedir (Şişman, 1998). Zira post-pozitivizme göre sosyal dünya doğal bir gerçeklik olarak ele alınmaz. İnsan yaşamı doğadan farklı olarak yine insan tarafindan kültürel olarak inşa edildiğinden, bu yaşamı düzenleyen kural ve yasalar evrensel mahiyette olmayıp kültürel ve semboliktir. Daha da açık ifade edilecek olursa sosyal bilimler yasa-bağımlı nedensel bir yaklaşımla değil; anlamaya dayalı yorumsamacı bir yaklaşımla anlaşılabilinir veya açıklanabilinir (Sunar, 2008). Geleneksel bilim anlayışı olarak ele alınabilecek pozitivizm ve gelenek ötesi bir bakışa sahip post-pozitivizm bilimdeki epistemolojik tartışmaların iki zıt kutbunu temsil etmektedir. Her ne kadar post-pozitivistler tarafindan güçlü bir şekilde eleştirilere maruz kalsa da, pozitivist yaklaşımı esas alan deney ve gözleme dayalı bilimsel metodların doğa ve sosyal bilimlerde daha baskın olduğu görülebilmektedir (Şişman, 1998).

Bilimsel epistemolojik inanç, geçerli güvenilir bilimsel bilginin ne olduğu, nasıl üretildiği ve nasıl paylaşıldığına ilişkin kişinin felsefik bakış açısını yansıtır. (Deryakulu ve Bıkmaz, 2003). Bu bağlamda kişinin bilginin kaynağına ilişkin inancı, bilimsel bilgiyi nasıl üreteceğini de gösteren bir olgudur. Bilimsel metedolojide çok sayıda yaklaşım ve paradigmanın ortaya çıkması ile birlikte bilimsel epistemolojik inanca olan ilgi artmıştır (Pomeroy, 1993). Çünkü bilimsel epistemolojik inanç bireylerin bilimsel bilginin doğasına ilişkin öznel bakış açılarını yansıtmakta ve özellikle eğitimcilerin de oldukça ilgi gösterdiği bir değişken olarak karşımıza çıkmaktadır. Literatürde öğretmenlerin ve öğrencilerin bilimsel epistemolojik inançları ile buna ilişkin bazı değişkenlerin araştırıldığı çalışmalara rastlamak mümkündür (Hammer, 1995; Pomeroy, 1993; Tsai, 1998; 1999). Bilimsel araştırmalara yönelik tutum ise, bireyin bir bilimsel araştırmada yer alıp almayacağına veya katkı sağlayıp sağlamayacağına ilişkin davranışlarını yansıtmaktadır (Korkmaz vd., 2011). Bilimsel yöntemlerle araştırma ve problemlere çözüm üretme kültürünün öğrencilere ve topluma yayılmasında en önemli role sahip öğretmenlerin bilimsel araştırmalara ve araştırmacılara yönelik olumlu tutum içerisinde olmaları önem arz etmektedir. Araştırma, sorgulama, gözlem ve deney yapma gibi tutum ve davranışlar bilgi toplumunun belirgin özellikleri arasındadır. $\mathrm{Bu}$ anlamda günümüz insanına bilimsel düşünce becerilerinin kazandırılmasında en önemli sorumluluk şüphesiz eğitim kurumlarına düşmektedir. Bu araştırmanın temel amacı ise eğitim fakültelerinde okutulan bilimsel araştırma yöntemleri dersinin etkililiğini test etmektir. Söz konusu amaca ulaşmak için aşağıdaki sorulara yanıtlar aranmıştır:

(i) Öğretmen adaylarının bilimsel epistemolojik inançları hangi düzeydedir?

(ii) Öğretmen adaylarının bilimsel araştırmalara yönelik tutumları hangi düzeydedir? 
(iii) Bilimsel araştırma yöntemleri dersinin öğretmen adaylarının bilimsel epistemolojik inançlarına ve bilimsel araştırmalara yönelik tutumlarına etkisi nedir?

(iv) Öğretmen adaylarının bilimsel epistemolojik inanç düzeyleri ile bilimsel araştırmalara yönelik tutum düzeyleri uygulama öncesinde ve sonrasında:

- Cinsiyete

- $\quad$ Lisedeki mezun oldukları alana

- Branşlarına göre anlamlı farklılık göstermekte midir?

\section{MODEL, VERİSETİ VE YÖNTEM}

\subsection{Yöntem}

$\mathrm{Bu}$ araştırma, eğitim fakültesinde okuyan öğretmen adaylarının aldıkları bilimsel araştırma yöntemleri dersinin etkililiğini test etmektedir. Bunun için bu araştırma deseni; deneme öncesi (pre-experimental) desenlerden tek gruplu ön-test-son-test modeline göre yapılandırılmıştır. Tek grup ön-test-son-test modelinde, gelişigüzel seçilmiş bir gruba bağımsız değişken uygulanır. Hem deney öncesi (ön-test) hem de deney sonrası (son-test) ölçmeler yapılır. Elde edilen ölçümler arasındaki farkın ön-test ile son-test arasında yapılan uygulamadan kaynaklandığı kabul edilir (Neuman, 2006). Modelin simgesel görünümü aşağıdaki gibidir:

$$
\begin{array}{llll}
\mathrm{G}_{1} & \mathrm{O}_{1.1} & \mathrm{X} & \mathrm{O}_{1.2}
\end{array}
$$

G1: Araştırma grubu, $\mathrm{O}_{1.1}$ : Uygulama öncesi ölçme (Ön-test), X: Uygulama ( Bağımsız değişken) $\mathrm{O}_{1.2}$ : Uygulama sonrası ölçme (Son-test).

Modelde $\mathrm{O}_{1.1}$ ile $\mathrm{O}_{1.2}$ arasındaki farkın X uygulamasından kaynaklandığı kabul edilir ve bağımsız değişken olan X'in etkisi olarak yorumlanır. Bu araştırmada, bilimsel araştırma yöntemleri dersinin öğretmen adaylarının bilimsel epistemolojik inançları ve bilimsel araştırmalara yönelik tutumları üzerindeki etkisini test etmek amacıyla ders dönemi başında 135 öğrenciye "bilimsel epistemolojik inançlar ölçeğii" ve "bilimsel araştırmaya yönelik tutum ölçeği” uygulanmıştır. Öğretmen adaylarına haftada 2 saat olmak üzere 12 hafta boyunca toplam 24 saat eğitimde bilimsel araştırma yöntemleri dersi verilmiştir. Eğitimde bilimsel araştırma yöntemleri dersi YÖK'ün belirlemiş olduğu içerik doğrultusunda yapılandırılmıştır. Ders döneminin sonunda aynı ölçekler öğrencilere son test olarak uygulanmış ve iki ölçme sonucunda elde edilen puanlar arasındaki fark incelenmiştir.

\section{2. Çalışma Grubu}

Araştırmanın çalışma grubu, Muş Alparslan Üniversitesi Eğitim Fakültesinin 2015-2016 eğitim-öğretim yılının ikinci döneminde okul öncesi ve sınıf öğretmenliği bölümünde okuyan 135 öğrenciden oluşmuştur. Çalışma grubu Şubat-Mayıs ayları arasında toplam 12 haftalık bir dönemde bilimsel araştırma yöntemleri dersine katılan öğrencilerdir. 
Aşağıdaki tabloda çalışma grubunun demografik özelliklerine ilişkin bilgiler yar almaktadir.

Tablo 1. Çalışma Grubuna İlişkin Demografik Özellikler

\begin{tabular}{llcc}
\hline & \multicolumn{1}{c}{ Değişkenler } & N & $\%$ \\
\hline \multirow{2}{*}{ Cinsiyet } & Erkek & 37 & 27.4 \\
& Kadın & 98 & 72.6 \\
\hline \multirow{2}{*}{ Bölüm } & Sinıf Öğretmenliği & 87 & 64.4 \\
\cline { 2 - 4 } & Okul Öncesi Öğretmenliği & 48 & 35.6 \\
\hline \multirow{3}{*}{ Mezun Olunan Alan } & Sözel & 9 & 6.7 \\
\cline { 2 - 4 } & Sayısal & 2 & 1.5 \\
\cline { 2 - 4 } & Eşit Ağırlık & 124 & 91.9 \\
\hline
\end{tabular}

Tablo 1'de görüleceği üzere, araştırmada yer alan öğretmen adayları daha çok kadın (\% 72.6) ve ağırlıklı olarak sınıf öğretmenliği bölümünden (\% 64.4) okuyan adaylardan oluşmuştur. Öğretmen adaylarının lisedeyken daha çok eşit ağırlık alanı (\% 91.9) mezunu oldukları görülebilmektedir.

\subsection{Veri Toplama Araçları}

Araştırmada veri toplama aracı olarak, Pomeroy (1993) tarafindan geliştirilen ve Deryakulu ve Bıkmaz (2003) tarafindan uyarlanan Bilimsel Epistemolojik Inançlar Ölçeği (Scientific Epistemological Beliefs Survey) ve Korkmaz vd. (2011) tarafindan geliştirilen Bilimsel Araştırmaya Yönelik Tutum Ölçeği kullanılmıştır. Bilimsel Epistemolojik İnançlar ölçeği beşli likert tipi maddelerden oluşan 30 maddelik bir ölçektir. Bu ölçek temelde bireylerin bilim anlayışlarını gösteren iki uçlu bir yapıdadır. Ölçekte yer alan 30 maddenin geleneksel bilim anlayışını yansıtan 22 maddesi olumlu $(+)$, geleneksel olmayan bilim anlayışını yansıtan 8 maddenin ise olumsuz (-) yönde kodlanmaktadır. Ölçeğin toplamından alınan puanın yüksek olması geleneksel bilim anlayışına sahip olunduğunu, düşük olması ise geleneksel olmayan bilim anlayışına sahip olunduğunu göstermektedir. Geleneksel bilim anlayışı deneyci-pozitivist paradigmayı geleneksel olmayan bilim anlayışı ise yapılandırmacı-postmodern paradigmayı temsil etmektedir. Uyarlama çalışmasında söz konusu ölçeğin güvenilirliğini belirlemek üzere madde analizine dayalı olarak hesaplanan Cronbach Alpha içtutarlılık katsayısı 0.91 olarak hesaplanmıştır (Deryakulu ve Bıkmaz, 2003). Çalışmamızda ise söz konusu Cronbach Alpha içtutarlılık katsayısı 0.89 olarak hesaplanmıştır.

Bilimsel Araştırmalara Yönelik Tutum ölçeği alanyazında bilimsel araştırmalara yönelik tutumları ölçmeyi amaçlayan farklı ölçeklerden (Elena, 2005; Walker, 2010) yararlanılarak geliştirilmiş beşli likert tipi bir ölçek olup dört faktör altında toplanabilen 30 maddeden oluşmaktadır. Elde edilen puanların yükselmesi birinci (Araştırmacılara Yardımcı Olmaya isteksizlik) ve ikinci (Araştırmalara Yönelik Olumsuz Tutum) faktörler için olumsuz tutumun arttığını, üçüncü (Araştırmalara Yönelik Olumlu Tutum) ve dördüncü (Araştırmacılara Yönelik Olumlu Tutum) faktörlerde ise olumlu tutumun arttığını göstermektedir. İlk iki faktörler son iki faktörler birbirlerine ters orantılıdır. Birinci ve ikinci faktörde yer alan maddelerin tamamı olumsuz ifadelerdir. Üçüncü ve 
dördüncü faktörlerde yer alan ifadeler ise olumludur. Dolayısıyla ilk iki faktörden elde edilen yüksek puanlar olumsuzluğu, üçüncü ve dördüncü faktörlerdeki yüksek puanlar ise olumluluğu ifade etmektedir. Bu ters orantıdan dolayı ölçeğin bütünü için bir toplam puanın hesap edilmesi anlamlı olmayıp, faktörler üzerinde ayrı ayrı işlem yapılmasını gerekli kılmaktadır. İlgili ölçeğin boyutlarına ilişkin Cronbach Alpha içtutarlılık katsayısı 0.76 ile 0.85 arasında hesaplanmıştır (Korkmaz vd., 2011). Çalışmamızda ise söz konusu ölçeğin boyutları açısından Cronbach Alpha içtutarlılık katsayısı 0.78 ile 0.87 arasında değiştiği tespit edilmiştir.

\subsection{Verilerin Analizi}

$\mathrm{Bu}$ araştırmada, bilimsel araştırma yöntemleri dersini alan öğretmen adaylarının her iki ölçeğin genelinde ve alt boyutlarında ön-test ve son-test puanlarının farklılık gösterip göstermediğini belirlemek amacıyla ilişkili gruplar $t$-testinin (paired $t$-test) uygulanmasının doğru analiz yöntemi olduğuna karar verilmiştir (Brace, Kemp \& Snelgar, 2003). Ayrıca bağımsız değişkenin bağımlı değişken üzerindeki etki büyüklüğünü anlamak için etki büyüklük katsayısı olan (d) hesaplanmıştır. Diğer taraftan ön-testte ve son-testte ölçeğin genelinde ve alt boyutlarında öğretmen adaylarının bilimsel epistemolojik inançları ve bilimsel araştırmalara yönelik tutumları cinsiyet, mezun oldukları lise alan türü ve okudukları bölüm değişkenleri açısından farklılık gösterip göstermediğini belirlemek amacıyla bağımsız gruplar $t$-testi (independent $t$-test) uygulanmıştır.

\subsection{Dersin Yapıs1}

Bu çalışma Muş Alparslan Üniversitesi Eğitim Fakültesinde 2015-2016 eğitim-öğretim yılı bahar yarıyılında toplam 12 haftalık ders döneminde bilimsel araştırma yöntemleri dersine katılan öğrencilerle gerçekleştirilmiş̧ir. İlk derste araştırmacı tarafından araştırmada veri toplama aracı olarak kullanılmaya karar verilen her iki ölçek de öğrencilere ön-test olarak uygulanmıştır. Daha sonra dönem boyunca öğretim üyesi olan araştırmacı tarafından bilimsel araştırma dersi kapsamındaki konular anlatılmıştır. Ders dönemi içerisinde dönem sonunda teslim edilmek üzere tüm öğrencilerden biri nicel araştırma yaklaşımına dayalı diğeri nitel araştırma yaklaşımına dayalı olma zorunluluğunda iki adet bilimsel makale ve bir lisansüstü tez incelettirilmiştir. Tüm öğrenciler inceledikleri bilimsel araştırmaların inceleme raporlarını araştırmacıya teslim etmişlerdir. Ayrıca tüm öğrencilerden eğitim ile ilgili bir problem durumunu belirleyerek bu problemin çözümünde bilimsel araştırma yöntemlerinden yararlanarak nasıl çözüm getirebileceklerine ilişkin bir rapor hazırlamaları da istenmiştir. Böylelikle ilgili ders sadece teorik bilgi aktarımından ibaret bırakılmamış, öğrencilerin araştırmaincelemelerine olanak sağlayacak şekilde yapılandırılmıştır. Dönem sonunda ön-test grubunda yer alan aynı öğrencilere her iki ölçek son-test olarak uygulanmıştır. Katılımcıların hepsinde gönüllülük esas alınmış, araştırmaya katılmak istemeyen öğrencilere hiçbir şekilde müdahale edilmemiştir. 


\subsection{Bulgular}

12 hafta süren ders dönemi sonunda öğrencilerden elde edilen ön-test ve son-test verilerinin uygun analiz sonuçları tablo 2'de verildi. Tablo 2'de görüldüğü üzere, öğretmen adaylarının bilimsel epistemolojik inançlar ölçeğinden aldıkları ön-test ve sontest puanları arasında istatistiksel olarak anlamlı bir farklılık yoktur $\left(\mathrm{t}_{(134)}=-.49, \mathrm{p}>.05\right)$. Öğretmen adaylarının bilimsel araştırma yöntemleri dersinden önceki ve sonraki bilimsel epistemolojik inançları arasında herhangi bir farklılığın olmadığı görülebilmektedir. Bilimsel araştırma yöntemleri dersinin öğretmen adaylarının epistemolojik inançları üzerindeki etkisi çok düşüktür $(\mathrm{d}=.04)$. Ölçeğin toplamından alınan puanın artması geleneksel/pozitivist bilim anlayışını yansıttığı göz önüne alındığında, öğretmen adaylarının uygulama öncesinde de $(X=3.47)$ sonrasinda da $(X=3.49)$ geleneksel/pozitivist bilimsel inanca sahip oldukları görülebilmektedir.

Öğretmen adaylarının bilimsel araştırmalara yönelik tutum ölçeğine verdikleri yanıtların analizinde, söz konusu ölçeğin 1. boyutu olan "araştırmacılara yardımcı olmaya isteksizlik" boyutuna verdikleri ön-test ve son-test puanları arasında istatiksel olarak anlamlı bir farklılığın olmadığı görüldü $\left(\mathrm{t}_{(134)}=.73\right.$, p>.05). Bununla birlikte katılımcıların ilgili ölçeğin 2. boyutu olan "araştırmalara yönelik olumsuz tutum" boyutuna verdikleri ön-test ve son-test puanları arasında da istatiksel olarak anlamlı bir farklılığın olmadığı görüldü $\left(\mathrm{t}_{(134)}=1.62, \mathrm{p}>.05\right)$. 3. Boyut olan "Araştırmalara yönelik olumlu tutum" boyutu açısından ise ön-test ve son-test puanları arasındaki farkın son test lehine istatistiksel olarak anlamlı olduğu anlaşıldı $\left(\mathrm{t}_{(134)}=-5.45, \mathrm{p}<.01\right)$. Bu bulgu, öğretmen adaylarının bilimsel araştırma yöntemleri dersini gördükten sonra bilimsel araştırmaları daha fazla önemseme, bilimsel araştırma raporlarını okumaktan zevk alma, firsatı yakaladığında bilimsel araştırma yapmayı isteme gibi bilimsel araştırmalara yönelik olumlu tutumlarında önemli düzeyde gelişme kaydettikleri anlaşılmaktadır. Etki düzeyi sınıflaması bakımından değerlendirildiğinde, bu dersin ilgili boyut üzerin orta düzeyde (d=.47) (Green \& Salking, 2005) bir etkisinin olduğu görülebilmektedir. BATÖ'nün 4. Boyutu olan “Araştırmacılara yönelik olumlu tutum” boyutu açısından da ön-test ve son-test puanları arasındaki farkın son test lehine istatistiksel olarak anlamlı olduğu görülmektedir $\left(\mathrm{t}_{(134)}=-2.62, \mathrm{p}<.01\right)$. Bu bulgu, öğretmen adaylarının uygulama sonrasında bilim insanlarının daha nitelikli, evrensel düşünebilen, objektif ve ahlaki sorumluluğu yüksek bireyler olarak evreni anlamaya ve açıklamaya çalışan saygın bireyler olduğuna inanma gibi araştırmacılara yönelik tutumlarında önemli düzeyde olumlu bir artışın olduğu anlaşılmaktadır. Bilimsel araştırma yöntemleri dersinin ölçeğin 4. boyutu üzerinde de orta düzeyde $(\mathrm{d}=.23)$ bir etkiye sahip olduğu görülmektedir. 
Tablo 2. Öğretmen Adaylarının Ön-Test ve Son-Test Puanlarının İlişkili Gruplar t Testi Sonuçları

\begin{tabular}{|c|c|c|c|c|c|c|c|c|}
\hline Bağımlı Değişken & Gruplar & $\mathrm{N}$ & $X$ & Ss & $\mathrm{sd}$ & $\mathrm{t}$ & $\mathrm{p}$ & d \\
\hline \multirow{2}{*}{$\begin{array}{l}\text { Bilimsel Epistemolojik İnançlar } \\
\text { Ölçeği }\end{array}$} & Ön-test & \multirow{2}{*}{135} & 3.47 & .26 & \multirow{2}{*}{134} & \multirow{2}{*}{-.49} & \multirow{2}{*}{.61} & \multirow{2}{*}{.04} \\
\hline & Son-test & & 3.49 & .30 & & & & \\
\hline \multirow{2}{*}{$\begin{array}{l}\text { Bilimsel Araştırmalara Yönelik } \\
\text { Tutum- 1. Boyut }\end{array}$} & Ön-test & \multirow{2}{*}{135} & 2.19 & .90 & \multirow{2}{*}{134} & \multirow{2}{*}{.73} & \multirow{2}{*}{.46} & \multirow{2}{*}{.06} \\
\hline & Son-test & & 2.12 & .95 & & & & \\
\hline \multirow{2}{*}{$\begin{array}{l}\text { Bilimsel Araştırmalara Yönelik } \\
\text { Tutum- 2. Boyut }\end{array}$} & Ön-test & \multirow{2}{*}{135} & 1.83 & .68 & \multirow{2}{*}{134} & \multirow{2}{*}{1.62} & \multirow{2}{*}{.10} & \multirow{2}{*}{.14} \\
\hline & Son-test & & 1.72 & .67 & & & & \\
\hline \multirow{2}{*}{$\begin{array}{l}\text { Bilimsel Araştırmalara Yönelik } \\
\text { Tutum- 3. Boyut }\end{array}$} & Ön-test & \multirow{2}{*}{135} & 3.21 & .87 & \multirow{2}{*}{134} & - & \multirow{2}{*}{$.00 *$} & \multirow{2}{*}{.47} \\
\hline & Son-test & & 3.68 & .98 & & 5.45 & & \\
\hline \multirow{2}{*}{$\begin{array}{l}\text { Bilimsel Araştırmalara Yönelik } \\
\text { Tutum- 4. Boyut }\end{array}$} & Ön-test & \multirow{2}{*}{135} & 3.96 & .85 & \multirow{2}{*}{134} & & \multirow{2}{*}{$.01 *$} & \multirow{2}{*}{.23} \\
\hline & Son-test & & 4.18 & .80 & & 2.62 & & \\
\hline
\end{tabular}

Tablo 3'te öğretmen adaylarının her iki ölçeğe verdikleri puanın cinsiyete göre farklılık gösterip göstermediğine ilişkin bağımsız gruplar t testi sonuçları verilmiştir. Bulgular, hem ön-test hemde son-test açısından kız öğretmen adayları ile erkek öğretmen adaylarının "bilimsel epistemolojik inançları" ve "bilimsel araştırmalara yönelik tutumları"nın (tüm boyutlarda) istatistiksel olarak anlamlı bir farklılık oluşturmadığını göstermiştir.

Tablo 3. Öğretmen Adaylarının Cinsiyete Göre Bilimsel Epistemolojik İnançları ve Bilimsel Araştırmalara Yönelik Tutumları

\begin{tabular}{|c|c|c|c|c|c|c|c|c|}
\hline Bağımlı Değişken & Gruplar & Cinsiyet & $\mathrm{N}$ & $X$ & ss & $\mathrm{sd}$ & $\mathrm{T}$ & $\mathrm{p}$ \\
\hline \multirow{4}{*}{$\begin{array}{l}\text { Bilimsel Epistemolojik } \\
\text { İnançlar Ölçeği }\end{array}$} & \multirow{2}{*}{ Ön-test } & Erkek & 37 & 3.43 & ,27 & \multirow{2}{*}{133} & \multirow{2}{*}{-.91} & \multirow{2}{*}{.36} \\
\hline & & $\mathrm{K}_{1 \mathrm{Z}}$ & 98 & 3.49 &, 30 & & & \\
\hline & \multirow{2}{*}{ Son-test } & Erkek & 37 & 3.78 & ,96 & \multirow{2}{*}{133} & \multirow{2}{*}{.71} & \multirow{2}{*}{.43} \\
\hline & & $\mathrm{K}_{1 \mathrm{Z}}$ & 98 & 3.65 &, 89 & & & \\
\hline \multirow{4}{*}{$\begin{array}{l}\text { Bilimsel Araştırmalara } \\
\text { Yönelik Tutum- 1. Boyut }\end{array}$} & \multirow{2}{*}{ Ön-test } & Erkek & 37 & 2.40 & ,91 & \multirow{2}{*}{133} & \multirow{2}{*}{1.64} & \multirow{2}{*}{.10} \\
\hline & & $\mathrm{K} 1 \mathrm{z}$ & 98 & 2.11 &, 89 & & & \\
\hline & \multirow{2}{*}{ Son-test } & Erkek & 37 & 2.20 & ,93 & \multirow{2}{*}{133} & \multirow{2}{*}{.63} & \multirow{2}{*}{.52} \\
\hline & & $\mathrm{K} 1 \mathrm{Z}$ & 98 & 2.09 & ,96 & & & \\
\hline \multirow{4}{*}{$\begin{array}{l}\text { Bilimsel Araştırmalara } \\
\text { Yönelik Tutum- 2. Boyut }\end{array}$} & \multirow{2}{*}{ Ön-test } & Erkek & 37 & 1.90 &, 60 & \multirow{2}{*}{133} & \multirow{2}{*}{.70} & \multirow{2}{*}{.48} \\
\hline & & $\mathrm{K}_{1 \mathrm{Z}}$ & 98 & 1.81 &, 71 & & & \\
\hline & \multirow{2}{*}{ Son-test } & Erkek & 37 & 1.87 &, 74 & \multirow{2}{*}{133} & \multirow{2}{*}{1.56} & \multirow{2}{*}{.12} \\
\hline & & $\mathrm{K}_{1 \mathrm{Z}}$ & 98 & 1.67 & 64 & & & \\
\hline \multirow{4}{*}{$\begin{array}{l}\text { Bilimsel Araştırmalara } \\
\text { Yönelik Tutum- 3. Boyut }\end{array}$} & \multirow{2}{*}{ Ön-test } & Erkek & 37 & 3.18 & , 88 & \multirow{2}{*}{133} & \multirow{2}{*}{-.21} & \multirow{2}{*}{.82} \\
\hline & & $\mathrm{K}_{1 \mathrm{Z}}$ & 98 & 3.22 & 87 & & & \\
\hline & \multirow{2}{*}{ Son-test } & Erkek & 37 & 3.78 &, 93 & \multirow{2}{*}{133} & 72 & 46 \\
\hline & & $\mathrm{K} 1 \mathrm{z}$ & 98 & 3.65 & ,99 & & .72 & .46 \\
\hline & & Erkek & 37 & 3.90 &, 84 & & & \\
\hline Bilimsel Araştırmalara & On-test & $\mathrm{K}_{1 \mathrm{Z}}$ & 98 & 3.99 &, 86 & 133 & -.5 & .58 \\
\hline Yönelik Tutum- 4. Boyut & & Erkek & 37 & 4.10 & ,78 & 133 & -6 & 50 \\
\hline & Son-te & $\mathrm{K}_{12}$ & 98 & 4.21 &, 81 & 133 & $-.6 /$ & (50 \\
\hline
\end{tabular}

Tablo 4'te öğretmen adaylarının her iki ölçeğe verdikleri puanın okudukları bölüme göre farklılık gösterip göstermediğine ilişkin bağımsız gruplar t testi sonuçları verilmiştir. Bulgular, hem ön-test hem de son-test açısından sınıf öğretmeni adayları ile okul öncesi 
öğretmen adaylarının "bilimsel epistemolojik inançları" ve "bilimsel araştırmalara yönelik tutumları"nın (tüm boyutlarda) istatistiksel olarak anlamlı bir farklılık oluşturmadığını göstermiştir.

Tablo 4. Öğretmen Adaylarının Okudukları Branşa Göre Bilimsel Epistemolojik İnançları ve Bilimsel Araştırmalara Yönelik Tutumları

\begin{tabular}{|c|c|c|c|c|c|c|c|c|}
\hline Bağımlı Değişken & Gruplar & Bölüm & $\mathrm{N}$ & $\mathrm{X}$ & ss & sd & $\mathrm{T}$ & $\mathrm{p}$ \\
\hline \multirow{4}{*}{$\begin{array}{l}\text { Bilimsel Epistemolojik } \\
\text { İnançlar Ölçeği }\end{array}$} & \multirow{2}{*}{ Ön-test } & Okul Öncesi & 48 & 3.41 & .38 & \multirow{2}{*}{133} & & \multirow{2}{*}{.14} \\
\hline & & Sinif & 87 & 3.50 & .24 & & 1.47 & \\
\hline & \multirow{2}{*}{ Son-test } & Okul Öncesi & 48 & 3.49 & .33 & \multirow{2}{*}{133} & \multirow{2}{*}{.20} & \multirow{2}{*}{.83} \\
\hline & & Sinıf & 87 & 3.48 & .22 & & & \\
\hline \multirow{4}{*}{$\begin{array}{l}\text { Bilimsel Araştırmalara } \\
\text { Yönelik Tutum- 1. Boyut }\end{array}$} & \multirow{2}{*}{ Ön-test } & Okul Öncesi & 48 & 2.27 & .96 & \multirow{2}{*}{133} & \multirow{2}{*}{.79} & \multirow{2}{*}{.42} \\
\hline & & Sinif & 87 & 2.14 & .86 & & & \\
\hline & \multirow{2}{*}{ Son-test } & Okul Öncesi & 48 & 2.21 & .95 & \multirow{2}{*}{133} & \multirow{2}{*}{.82} & \multirow{2}{*}{.41} \\
\hline & & Sinıf & 87 & 2.07 & .95 & & & \\
\hline \multirow{4}{*}{$\begin{array}{l}\text { Bilimsel Araştırmalara } \\
\text { Yönelik Tutum- 2. Boyut }\end{array}$} & \multirow{2}{*}{ Ön-test } & Okul Öncesi & 48 & 1.95 & .95 & \multirow{2}{*}{133} & \multirow{2}{*}{1.48} & \multirow{2}{*}{.14} \\
\hline & & Sinıf & 87 & 1.77 & .47 & & & \\
\hline & \multirow{2}{*}{ Son-test } & Okul Öncesi & 48 & 1.77 & .81 & \multirow{2}{*}{133} & \multirow{2}{*}{.52} & \multirow{2}{*}{.59} \\
\hline & & Sinıf & 87 & 1.70 & .59 & & & \\
\hline \multirow{4}{*}{$\begin{array}{l}\text { Bilimsel Araştırmalara } \\
\text { Yönelik Tutum- 3. Boyut }\end{array}$} & \multirow{2}{*}{ Ön-test } & Okul Öncesi & 48 & 3.40 & .82 & \multirow{2}{*}{133} & \multirow{2}{*}{1.87} & \multirow{2}{*}{.06} \\
\hline & & Sinif & 87 & 3.11 & .89 & & & \\
\hline & \multirow{2}{*}{ Son-test } & Okul Öncesi & 48 & 3.69 & .90 & \multirow{2}{*}{133} & \multirow{2}{*}{.10} & \\
\hline & & Sinif & 87 & 3.68 & 1.02 & & & .91 \\
\hline & & Okul Öncesi & 48 & 3.87 & .99 & & & \\
\hline Bilimsel Araștırmalara & On-test & Sinif & 87 & 4.01 & .76 & 133 & -.92 & .35 \\
\hline Yönelik Tutum- 4. Boyut & & Okul Öncesi & 48 & 4.20 & .80 & & & \\
\hline & Son-test & Sinif & 87 & 4.17 & .81 & 135 & .22 & .82 \\
\hline
\end{tabular}

Tablo 5'te öğretmen adaylarının her iki ölçeğe verdikleri puanın liseden mezun oldukları alana göre farklılık gösterip göstermediğine ilişkin bağımsız gruplar t testi sonuçları verilmiştir. Bulgular, hem ön-test hem de son-test açısından eşit ağırlık (EA) ve sözel alan mezunlarının "bilimsel epistemolojik inançları" ve "bilimsel araştırmalara yönelik tutumları"nın (tüm boyutlarda) istatistiksel olarak anlamlı bir farklılık oluşturmadığını göstermiştir. 
Tablo 5. Öğretmen Adaylarının Okudukları Mezun Oldukları Alana Göre Bilimsel Epistemolojik İnançları ve Bilimsel Araştırmalara Yönelik Tutumları

\begin{tabular}{|c|c|c|c|c|c|c|c|c|}
\hline Bağımlı Değişken & Gruplar & Bölüm & $\mathrm{N}$ & $\mathrm{X}$ & ss & $\mathrm{sd}$ & $\mathrm{t}$ & $\mathrm{p}$ \\
\hline \multirow{4}{*}{$\begin{array}{l}\text { Bilimsel Epistemolojik } \\
\text { İnançlar Ölçeği }\end{array}$} & \multirow{2}{*}{ Ön-test } & Sayısal & 9 & 3.50 & .31 & \multirow{2}{*}{131} & \multirow{2}{*}{.20} & \multirow{2}{*}{.83} \\
\hline & & EA & 124 & 3.47 & .30 & & & \\
\hline & \multirow{2}{*}{ Son-test } & Sayısal & 9 & 3.53 & .24 & \multirow{2}{*}{131} & \multirow{2}{*}{.51} & \multirow{2}{*}{.60} \\
\hline & & EA & 124 & 3.48 & .26 & & & \\
\hline \multirow{4}{*}{$\begin{array}{l}\text { Bilimsel Araştırmalara } \\
\text { Yönelik Tutum- 1. Boyut }\end{array}$} & \multirow{2}{*}{ Ön-test } & Sayısal & 9 & 2.13 & .72 & \multirow{2}{*}{131} & \multirow{2}{*}{-.15} & \multirow{2}{*}{.87} \\
\hline & & EA & 124 & 2.18 & .91 & & & \\
\hline & \multirow{2}{*}{ Son-test } & Sayısal & 9 & 1.93 & .96 & \multirow{2}{*}{131} & \multirow{2}{*}{-2.19} & \multirow{2}{*}{.15} \\
\hline & & EA & 124 & 1.76 & .46 & & & \\
\hline \multirow{4}{*}{$\begin{array}{l}\text { Bilimsel Araştırmalara } \\
\text { Yönelik Tutum- 2. Boyut }\end{array}$} & \multirow{2}{*}{ Ön-test } & Sayısal & 9 & 1.48 & .46 & \multirow{2}{*}{131} & \multirow{2}{*}{-1.61} & \multirow{2}{*}{.10} \\
\hline & & EA & 124 & 1.86 & .70 & & & \\
\hline & \multirow{2}{*}{ Son-test } & Sayısal & 9 & 1.44 & .56 & \multirow{2}{*}{131} & \multirow{2}{*}{-1.32} & \multirow{2}{*}{.18} \\
\hline & & EA & 124 & 1.75 & .68 & & & \\
\hline \multirow{4}{*}{$\begin{array}{l}\text { Bilimsel Araştırmalara } \\
\text { Yönelik Tutum- 3. Boyut }\end{array}$} & \multirow{2}{*}{ Ön-test } & Sayısal & 9 & 3.42 & .91 & \multirow{2}{*}{131} & \multirow{2}{*}{.77} & \multirow{2}{*}{.44} \\
\hline & & EA & 124 & 3.19 & .88 & & & \\
\hline & \multirow{2}{*}{ Son-test } & Sayısal & 9 & 3.84 & 1.12 & \multirow{2}{*}{131} & & \\
\hline & & EA & 124 & 3.67 & .96 & & .49 & .61 \\
\hline & Ön_test & Sayısal & 9 & 4.27 & .56 & 131 & 109 & 27 \\
\hline Bilimsel Araștırmalara & Untelest & EA & 124 & 3.95 & .85 & 151 & 1.09 & .21 \\
\hline Yönelik Tutum- 4. Boyut & Son- & Sayısal & 9 & 4.48 & .70 & 131 & 116 & 24 \\
\hline & Sont-lest & EA & 124 & 4.16 & .78 & 151 & 1.10 & .24 \\
\hline
\end{tabular}

\section{SONUÇ VE DEĞERLENDİRME}

Türkiye'de öğretmen yetiştirme sorumluluğunu üstlenen YÖK, 2007 yılından itibaren eğitim fakültelerinin tüm bölümlerinde "bilimsel araştırma yöntemleri” dersini 2 kredilik zorunlu dersler arasına almıştır. Bu dersin içeriği ve kapsamı dikkate alındığında temel amacının öğretmen adaylarını bilimin temel kavramları hakkında bilgilendirerek bilimin kabul ettiği yöntemlere vakıf, bir problemin çözümünde bilimden yaralanabilen ve bilimsel çalışmaları anlayıp yorumlayabilen bireyler olarak yetiştirmek olduğu anlaşılabilmektedir. Özetle bu ders "araştırmacı öğretmenlerin" (Tomakin, 2007) yetiştirilmesine katkıda bulunmak üzere yapılandırılmış ve müfredata eklenmiş bir ders olarak görülebilir. Bilimden ve bilimsel araştırma yöntemlerinden anlayan ve aynı zamanda kendi öğrencilerine bir problemin çözümünde bilimsel yöntemlerden nasıl yaralanabilecekleri konusunda rehberlik yapma sorumluluğunu üstlenen öğretmen adaylarına okutulan bu dersin etkililiği konusunda araştırmaların yapılması gerekliliği dikkate alındığında; bu araştırmada elde edilen bulguların alana getireceği katkıların göz ardı edilemeyeceği düşünülebilir. Eğitim fakültelerinde öğretmenlik meslek bilgisi dersi olarak okutulan tüm derslerin ortak amacı nitelikli ve donanımlı öğretmenler yetiştirmektir. $\mathrm{Bu}$ anlamda literatürde eğitim fakültesinde okutulan derslerin etkililiğini konu alan araştırmalara rastlamak mümkündür (Çoğaltay, 2015; Ekici, 2008; Tomakin, 2007).

Araştırmada elde edilen bulgular, öğretmen adaylarının bilimsel epistemolojik inançlarının bilimsel araştırma yöntemleri dersini almaları ile herhangi bir değişikliğe 
uğramadığını, bu dersin öğretmen adaylarının epistemolojik inançları üzerinde herhangi bir etkisinin olmadığını göstermektedir. Öğretmen adaylarının bu dersi almadan önceki ön-test sonucu bilimsel epistemolojik inanç düzeyi $X=3.47 \mathrm{iken}$, bu dersi aldıktan sonraki son-test düzeyi $\mathrm{X}=3.49$ 'dır. Bilimsel epistemolojik inançlar ölçeğinden alınan hem öntest hem de son-test puanları öğretmen adaylarının "geleneksel/pozitivist bilim anlayışına" sahip olduklarını göstermektedir. Bu bulgu öğretmen adaylarının, geçerli ve güvenilir bilgi üretmenin pozitivist bakış açısıyla ve onun gerekliliklerini karşılayan bilimsel metodoloji aracılığıyla üretilebileceğine inandıklarını göstermektedir. Araştırmada elde edilen bu bulgu literatürce desteklenmektedir. Pomeroy (1993), farklı disiplinlerde çalışan bilim adamlarının, öğretmenlerin ve öğrencilerin daha çok geleneksel/pozitivist bilim anlayışını benimsediklerini tespit etmiştir.

Öğretmen adaylarının hem ön-test hem de son test sonuçlarına göre geleneksel bilim anlayışına sahip olmalarını iki açıdan değerlendirmek mümkündür. Birincisi, Türk eğitim sistemi içerisinde tüm öğretim kademelerinde geleneksel bilim anlayışının hâkim olması ve öğrencilere sadece deney ve gözleme dayalı nicel bilgilerin doğru ve güvenilir olduğu bakış açısının kazandırılmaya çalışılmasıyla ve aynı zamanda her alanda (tıpta, fizikte, coğrafyada vb.) baskın olarak görülen pozitivist paradigmanın bilimsel bilginin üretimindeki tek geçerli yol olduğu şeklindeki yaratılan algının etkisiyle, kolaylıkla kırılamayacak düzeyde katı geleneksel/pozitivist epistemolojik inanca sahip bireyler yetişmiştir. Bu katı inanç lisans düzeyinde okutulan bir dersten etkilenmemiştir. İkincisi ise, eğitim fakültelerinde okutulan bilimsel araştırma yöntemleri dersinin içeriği ve süresi öğretmen adaylarının bilimsel epistemolojik inançlarını sorgulayabilmesine imkân yaratacak bir etkililikte olmayışıdır. Söz konusu dersin bir dönemlik ve 2 kredilik bir ders olduğu dikkate alındığında, birçok kolay anlaşılamayan veya karmaşık kavramları barındıran bilim ve bilimsel araştırma yöntemleri gibi bir alanın öğretmen adayları tarafından kısa bir süre içerisinde anlaşılması ve eleştirel bir bakışla gözden geçirilerek analiz edilmesinin çok da kolay olamayacağı anlaşılabilir. Dersin içeriği dikkate alındığında, ders kapsamının büyük çoğunluğunu geleneksel bilim anlayışını yansıtan nicel yöntemlerin veya kavramların oluşturduğu görülebilmektedir. Bu durum zaten o güne kadarki sahip olunan bilimsel epistemolojik inancı olumlu veya olumsuz yönde etkilememiştir. Her ne kadar derste her iki bilim anlayışının (geleneksel ve geleneksel ötesi) temel dayanakları ve yöntemlerinin özellikleri açıklanmışsa da; öğretmen adayları daha çok nicel araştırma yöntemlerini benimsemişlerdir. Dersin gereği olarak öğretmen adaylarından istenilen eğitimle ilgili bir problem durumuna bilimsel araştırma yöntemlerine uygun bir şekilde çözüm önerisinin geliştirilmesine ilişkin raporlar incelendiğinde, 135 öğrenciden 117'sinin nicel araştırma yöntemlerinden yararlandığı (deneysel desen, tarama modeli, anket, daha çok sayısal istatistiki veriler vb.), geri kalan 18 öğrencinin ise nitel araştırma yöntemlerinden yararlandıkları (görüşme, mülakat, yerinde gözlem vb.) gözlemlendi. Bu tespit araştırmada kullanılan ölçeğin katılımcı öğretmen adaylarının epistemolojik inançlarını doğru şekilde yansıttığını da göstermektedir. Ayrıca araştırmada belirlenen bağımsız değişkenler açısından (cinsiyet, branş ve lisedeki mezun olunan alan) öğretmen adaylarının ön-test ve son-test sonuçlarında herhangi istatistiksel olarak anlamlı bir farklılığın olmaması da dikkat çekicidir. Bu durum geleneksel bilimsel epistemolojik inancın güçlü bir şekilde eğitim sistemimizin içerisinde olduğunu ve cinsiyet, alan ve bölüm gibi demografik değişkenlerin bu inanc1 etkilemediğini göstermektedir. 
Araştırmanın diğer bağımlı değişkeni öğretmen adaylarının bilimsel araştırmalara yönelik tutumlarıdır. Bu değişkenin ölçülmesinde kullanılan bilimsel araştırmalara yönelik tutum ölçeği 4 boyutlu bir yapıda olduğundan her bir boyuta ilişkin yapılan analiz sonuçları incelendiğinde, öğretmen adaylarının ölçeğin "araştırmacılara yardımcı olmaya isteksizlik" ve "araştırmalara yönelik olumsuz tutum" boyutları açısından ön-test ve sontest puanları arasında anlamlı bir farklılığın olmadığı anlaşılmıştır. Bu bulgu öğretmen adaylarının bilimsel araştırmalara yönelik olumsuz tutumlarını yansıtan bu iki boyut açısından bir dönemlik ilgili dersin herhangi bir etkisinin olmadığını göstermiştir. Öğretmen adaylarının "araştırmacılara yardımcı olmaya isteksizlik" boyutundaki ön-test $(X=2.19)$ ve son-test $(X=2.12)$ sonuçları ile "araştırmalara yönelik olumsuz tutum" " boyutundaki ön-test $(X=1.83)$ ve son-test $(X=1.72)$ sonuçları öğretmen adaylarının hem uygulama öncesinde hem de uygulama sonrasında bilimsel araştırmalara yönelik olumsuz tutum içinde olmadıklarını göstermektedir. Bu bulgu, ilgili dersin öğretmen adaylarında bilimsel araştırmalara yönelik olumsuz tutum gelişimine yol açmadığını göstermesi bakımından önemlidir. Araştırmadaki diğer bulgu, öğretmen adaylarının ölçeğin "araştırmalara yönelik olumlu tutum" ve "araştırmacılara yönelik olumlu tutum" boyutları açısından ön-test ve son-test puanları arasında son-test lehine istatistiksel olarak anlamlı bir farklılığın olduğunu gösterdi. Bu bulgu, öğretmen adaylarının uygulama sonrasında bilimsel araştırmalara yönelik olumlu tutum düzeylerinde pozitif yönlü bir değişimin olduğunu gösterdi. Öğretmen adaylarının "araştırmalara yönelik olumlu tutum" boyutundaki ön-test $(X=3.21)$ ve son-test $(X=3.68)$ sonuçları ile "araştırmacılara yönelik olumlu tutum" boyutundaki ön-test $(X=3.96)$ ve son-test $(X=4.18)$ sonuçları öğretmen adaylarının bilimsel araştırmalara yönelik olumlu tutumlarının uygulama sonrasında arttığını göstermektedir. Bu bulgular ilgili dersi gören öğretmen adaylarının dönem sonunda bilimsel araştırmaları daha fazla önemsemeye başladıklarını, araştırma raporlarını okumaktan daha fazla hoşlanmaya başladıklarını, fırsat verildiğinde bilimsel araştırma yapmaya daha istekli olmaya başladıklarını, bilim insanlarının daha nitelikli, evrensel düşünebilen, objektif ve ahlaki sorumluluğu yüksek bireyler olarak evreni anlamaya ve açıklamaya çalışan saygın bireyler olduğuna daha fazla inanmaya başladıklarını göstermektedir. Öğretmen tutum ve davranışlarının öğrencilere kazandırılacak hedef ve davranışlarda önemli rol oynadığı değerlendirildiğinde (Kılıç ve Acat, 2007; Tekbıyık ve İpek, 2007), araştırmamızda elde edilen bulguların YÖK'ün 2007 yılından itibaren bilimsel araştırma yöntemleri dersini eğitim fakültelerindeki tüm bölümlerde zorunlu dersler arasına almasının isabetli bir karar olmasını göstermesi bakımından da önem arz etmektedir. Araştırmada belirlenen bağımsız değişkenler açısından (cinsiyet, branş ve lisedeki mezun olunan alan) öğretmen adaylarının ön-test ve son-test sonuçlarında herhangi istatistiksel olarak anlamlı bir farklılığa rastlanılmamıştır. Elde edilen bulgular ışığında aşağıdaki önerilerde bulunulabilir:

(i) Eğitim fakültelerinde zorunlu dersler arasında yer alan bir dönemlik ve 2 kredilik "bilimsel araştırma yöntemleri dersi" kredi ve süre bakımından uzatılmalıdır.

(ii) Bilimsel araştırma yöntemleri dersinin içeriği yeniden yapılandırılarak bilimdeki geleneksel ötesi paradigmanın (post-pozitivist) temellerini de yansıtacak yeterliliğe kavuşturulmalıdır. 
(iii) Öğretmen adaylarının bilimsel epistemolojik inançlarını ve bilimsel araştırmalara yönelik tutumlarını etkileyen diğer faktörlerle ilgili araştırmalar yapılabilir.

Benzer çalışmalar farklı branşlardaki öğretmen adayları ile yapılarak sonuçların karşılaştırılmasına olanak sağlanabilir.

\section{KAYNAKÇA}

Akyüz, Y. (2014). Türk Eğitim Tarihi: M.Ö. 1000- M.S. 2014. Ankara: Pegem Akademi.

Cafoğlu, Z. (1998). Eğitimde Küresel Kimlik. Yeni Türkiye Dergisi 21. Yüzyll Özel Saylsl. 4(19), 837-844.

Cohen, L., \& Manion, L. (1994). Research Methods in Education. London: Roudledge.

Çoğaltay, N. (2015). Eğitim Fakültelerinde Okutulan Öğretmenlik Meslek Bilgisi Derslerinin Etkililiğine İlişskin Öğrenci Görüşleri: Nitel Bir Araştırma. Eğitim ve Insani Bilimler Dergisi Teori ve Uygulama. 6(12), 51-66

Demircioğlu, İ. H. (2006). Sosyal Bilgiler Öğretmen Adaylarının 'Öğretim Paketi' Ödevine Yönelik Görüşleri. Kastamonu Eğitim Dergisi, 14(1), 161-172.

Deryakulu, D., \& Bıkmaz, F. H. (2003). Bilimsel Epistemolojik İnançlar Ölçeğinin Geçerlik Ve Güvenirlik Çalışması. Eğitim Bilimleri ve Uygulama, 2(4), 243-257.

Dillon, J. \& Maguire, M. (1998). Becoming A Teacher. Buckingham: Open University Press.

Ekici, G. (2008). Sınıf Yönetimi Dersinin Öğretmen Adaylarının Öğretmen Öz-Yeterlilik Alg1 Düzeyine Etkisi. Hacettepe Üniversitesi Eğitim Fakültesi Dergisi, 35, 98-110.

Elena C., \& Papanastasiou, E. C. (2005). Factor Structure of the "Attitudes Toward Research" Scale. Statistics Education Research Journal, 4(1), 16-26.

Engin, A. O. (2012). Öğretmen Yetiştirme Uygulamalarının Tarihsel Süreç Açısından Kısaca Değerlendirilmesi ve Eğitim Fakültelerimizin Temel Sorunları. EKEV Akademi Dergisi, 16 (52), 245-265.

Erden, M. (1998). Öğretmenlik Mesleğine Giriş. İstanbul: Alkım Yayınevi.

Ergün, M. (1987). Türkiye'de Öğretmen Yetiştirme Çalışmalarının Gelişmesi. Hacettepe Üniversitesi Eğitim Fakültesi Dergisi, 2, 10-18.

Greenfield, T. B. (1986). The Decline and Fall of Science in Educational Administration. Interchange, 17(2), 57-80.

Hammer, D. (1995). Epistemological Considerations in Teaching Introductory Physics. Science Education, 79 (4), 393-413.

Kılıç, A. ve Acat, M.B. (2007). Öğretmen Adaylarının Algılarına Göre Öğretmen Yetiştirme Programlarındaki Derslerin Gereklilik ve İşe Vurukluk Düzeyi. Manas Üniversitesi Sosyal Bilimler Dergisi, 17, 21-37. 
Korkmaz, Ö., Şahin, A., \& Yeşil, R. (2011). Bilimsel Araştırmaya Yönelik Tutum Ölçeği Geçerlilik ve Güvenirlik Çalışması. Ilkögretim Online, 10(3), 961-973.

Neuman, W. L. (2006). Social Research Method: Qualitative and Quantitative Approaches. Bacon USA: Pearson Education.

Nunan, D. (2004). Task-Based Language Teaching: A Comperehensively Revised Edition of Designing Tasks for the Communicative Classroom. Cambridge: Cambridge University Press.

Pomeroy, D. (1993). Implications of Teachers' Beliefs About the Nature of Science: Comparision of the Beliefs of Scientists, Secondary Science Teachers, and Elemantary Teachers. Science Education, 77(3), 261-278.

Sunar, İ. (2008). Düşün ve Toplum. İstanbul: Doruk Yayınları.

Şimşek, H. (1997). Pozitivizm Ötesi Paradigmatik Dönüşüm ve Eğitim Yönetiminde Kuram ve Uygulamada Yeni Yaklaşımlar. Kuram ve Uygulamada Eğitim Yönetimi, 3 (1), 95-109.

Şişman, M. (1998). Eğitim Yönetiminde Kuram ve Araştırmada Alternatif Paradigma ve Yaklaşımlar. Kuram Ve Uygulamada Eğitim Yönetimi, 4(4), 395-422.

Taşdemirci, E. (2010). Türk Eğitim Tarihi. Ankara: Gündüz Yayıncılık.

Tekbıyık, A. \& İpek, C. (2007). Sınıf Öğretmeni Adaylarının Fen Bilimlerine Yönelik Tutumları ve Mantıksal Düşünme Becerileri. YYÜ Eğitim Fakültesi Dergisi, 4(1), $102-117$.

Tomakin, E. (2007). Bilimsel Araştırma Yöntemleri Dersinin Etkin Öğretilmesinin İncelenmesi. Kazım Karabekir Ĕ̆itim Fakültesi Dergisi, 16, 37-65.

Tsai, C. C. (1998). An Analysis of Scientific Epistemological Beliefs and Learning Orientations of Taiwanese Eighth Graders. Science Education, 82(4), 473-489.

Tsai, C. C. (1999). Laboratory Exercises Help Me Memorize the Scientific Truths: A Study of Eighth Graders' Scientific Epistemological Views and Learning in Laboratory Activities. Science Education, 83(6), 654-674.

Walker, D. A. (2010). A Confirmatory Factor Analysis of the Attitudes Toward Research Scale. Multiple Linear Regression Viewpoints, 36 (1), 18-27.

YÖK (1998a). TC Yüksek Öğretim Kurulu Başkanlığı Eğitim Fakültesi Öğretmen Yetiştirme Lisans Programları. Ankara: YÖK

YÖK (1998b). Eğitim Fakülteleri Öğretmen Yetiştirme Programlarının Yeniden Düzenlenmesi. Ankara: YÖK

YÖK (2007). Öğretmen Yetiştirme ve Eğitim Fakülteleri (1982- 2007) Raporu. Ankara: YÖK 
